\title{
ANALISIS SISTEM INFORMASI AKUNTANSI DAN PENGENDALIAN INTERNAL PERSEDIAAN BAHAN BAKU \\ PADA KEDAI KOPI LEDOKAN di BINANGUN
}

\author{
Peneliti : \\ Novita Anjarsari(novitaanjarsari22@gmail.com) \\ Risky Nurfadila(kikyfadila1@gmail.com) \\ Iswatul Saldina(saldinaiswatul10@gmail.com)
}

\begin{abstract}
Abstrac
The accounting system is a tool used to organize or collect, collect, and conduct information regarding all company transactions, where employees, company activities, materials and machines can be integrated in such a way that supervision can be carried out. This study aims to find out how to analyze information systems and internal control of raw material supplies at the Ledokan Coffee shop in Binangun Blitar. The data used are qualitative data in the form of some basic analysis from field interviews. The results showed that the Ledokan Coffee Shop has good supply chain management capabilities as evidenced by the existence of suppliers who have long-term cooperative relationships with them.
\end{abstract}

Keywords: Accounting Information System, Inventory, Internal Contro

\begin{abstract}
Abstrak
Sistem akuntansi adalah alat yang digunakan untuk mengatur atau mengumpulkan, mengumpulkan, dan melakukan informasi mengenai semua transaksi perusahaan, di mana karyawan, kegiatan perusahaan, bahan dan mesin dapat diintegrasikan sedemikian rupa sehingga pengawasan dapat dilakukan.Penelitian ini bertujuan untuk mengetahui bagaimana menganalisis system informasi dan pengendalian internal persedian bahan baku pada kedai Kopi Ledokan di Binangun Blitar. Data yang digunakan adalah data kualitatif berupa beberapa analisis yang mendasar dari wawancara dilapangan. Hasil penelitian menunjukkan bahwa Kedai Kopi Ledokan memiliki kemampuan supply chain management yang baik yang dibuktikan dengan adanya pemasok yang memiliki hubungan kerjasama jangka panjang dengan mereka.
\end{abstract}

Kata kunci: Sistem Informasi Akuntansi, Persediaan, Pengendalian Internal 


\section{PENDAHULUAN}

Indonesia merupakan negara berkembang dimana berbagai industri juga berkembang pesat. Beberapa bidang usaha yang berkembang pesat adalah makanan, minuman, waralaba kopi dan lain-lain. Selain bisnis yang dikelola secara langsung, terdapat juga berbagai bisnis yang berkembang di dunia maya atau biasa dikenal dengan toko online, dimana dalam teknik pemasarannya sering menawarkan berbagai macam diskon. Sedangkan untuk waralaba makanan dan minuman, Anda dapat dengan mudah menemukannya di pinggir jalan maupun di mal dan kafe. Munculnya usaha-usaha tersebut juga dipengaruhi oleh beberapa faktor, antara lain kebutuhan masyarakat, tren perkembangan dan lain-lain.

Kedai kopi banyak ditemukan di kota-kota dengan populasi siswa yang tinggi, seperti kota-kota dengan banyak universitas dan sekolah. Selain itu, kafe juga akan hadir di kota-kota dengan populasi perkantoran tinggi. Keberadaan kedai kopi menjadi bukti bahwa menikmati kopi bukan lagi bentuk menikmati kopi tetapi sudah menjadi trend atau seni hidup kontemporer. Di Indonesia, dahulu kopi hanya diminum oleh orang dewasa, namun kini kopi menjadi minuman untuk segala usia dengan penyajian yang berbeda.

Tren kopi di Indonesia sendiri sedang berkembang karena beberapa faktor, salah satunya adalah Indonesia merupakan negara yang dapat menghasilkan berbagai macam kopi dengan aroma dan rasa yang khas. Selain dipengaruhi oleh daerah asal biji kopi, kelezatan biji kopi asli Indonesia juga dipengaruhi oleh cara kopi diseduh dan disajikan. Indonesia memproduksi beberapa kopi nikmatnya sendiri, baik Arabika maupun Robusta. Diantaranya adalah kafe Aceh gayo, kafe Tanah Toraja Toraja, kafe Bajawa Flores dan Wamena Papua, kafe Kintamani Bali, kafe Lereng Gunung Kawi dan masih banyak lagi kedai kopi lokal Indonesia lainnya.

Meningkatnya perdagangan kopi di Indonesia mendorong persaingan yang ketat antar pedagang kopi untuk menyesuaikan pasokan atau jumlah pemasok yang nantinya akan memberikan kontribusi bagi usaha tersebut. Pemilihan pemasok sangat penting karena bahan baku atau produk setengah jadi yang dibeli harus berkualitas tinggi. Bahan baku yang berkualitas tersebut kemudian akan menghasilkan produk yang berkualitas yang pada akhirnya akan mempengaruhi kepuasan konsumen terhadap produk yang dijual seperti barang atau jasa.

Selain pengelolaan bahan, pengelolaan biaya produksi juga memegang peranan penting. manajemen produksi sebagai pengaturan dan koordinasi penggunaan yang efektif dari berbagai sumber daya dan bahan baku untuk produksi dan menambah nilai pada produk yang dihasilkan. Sedangkan 
manajemen biaya produksi adalah pengelolaan biaya yang dikeluarkan dan keuntungan yang dihasilkan dalam proses produksi. Adanya manajemen produksi suatu perusahaan berguna untuk menghindari kekurangan biaya, baik dari segi biaya operasional, bahan baku, maupun peralatan produksi.

Salah satu kafe yang sedang berkembang di Kabupaten Blitar tepatnya di desa Sambigede Kecamatan Binangun adalah Kedai Kopi Ledokan. Lokasi kedai ini sangat strategis karena merupakan akses jalan menuju Kabupaten Malang, kawasan pemukiman, kawasan dekat dengan pabrik dan sering dikunjungi oleh masyarakat. Di antara sekian banyak kedai kopi yang bermunculan, Kedai Kopi Ledokan menonjol sebagai kafe khas dengan tagline "kopi asli Blitar". Dengan tagline tersebut, pelanggan dapat menikmati kopi single origin kualitas terbaik di toko ini. Tujuan dari penelitian ini adalah untuk menganalisis Sistem Informasi Akuntansi dan Pengendalian Internal Persediaan Bahan Baku Pada Kedai Kopi Ledokan Di Binangun Kabupaten Blitar.

\section{LANDASAN TEORI}

\section{Sistem}

Sistem merupakan sebuah kerangka dari prosedur-prosedur yang saling berhubungan satu sama lain yang disusun sesuai dengan suatu skema secara menyeluruh dan sistematis (Sofia, 2015). Sistem adalah sekumpulan komponen-komponen yang saling bekerjasama guna mencapai suatu tujuan. Masingmasing dari komponen itu sendiri memiliki fungsi yang berbeda dengan yang lain, akan tetapi dapat bekerjasama dengan baik. (Kusnendi, 2012) juga menyimpulkan bahwa Sistem ialah setiap sesuatu yang terdiri dari komponen-komponen, obyek-obyek, atau unsur-unsur yang bertata kaitan dan hubungan satu sama lain, sehingga unsur-unsur tersebut adalah satu kesatuan pemrosesan atau pengolahan yang tertentu.

Menurut (Kusnendi, 2012) Sistem juga dapat didefinisikan sebagai suatu kumpulan atau himpunan dari unsur, komponen atau variabel yang terorganisir, saling tergantung satu sama lain, saling berinteraksi, dan terpadu. Apa yang dimaksud dari komponen atau subsistem dalam penjelasan ini tak tak hanya komponen fisik semata, tetapi termasuk di dalamnya adalah komponen yang bersifat abstrak atau komponen secara konseptual, seperti , kebijakan, prosedur, visi, misi, dan kegiatan informal lainnya. Oleh karena itu dapat disimpulkan bahwa sistem adalah cara yang digunakan dalam sebuah organisasi guna untuk mencapai tujuan dalam suatu perusahaan.

\section{Sistem Akuntansi}

Sistem akuntansi yaitu sebuat alat yang digunakan untuk mengumpulkan, mengorganisir atau menyusun, dan mengikhtiarkan keterangan-keterangan yang bersangkutan dengan seluruh transaksi 
perusahaan, bahan-bahan, dimana para pegawai, kegiatan-kegiatan perusahaan, dan mesin-mesin dapat dipadukan agar nantinya pengawasan dapat berjalan dengan sebaik mungkin. Pengertian sistem akuntansi berdasarkan Bodnar dan Hopwood (2008:182) yaitu suatu organisasi yang terdiri dari metode yang digunakan serta catatan-catatan yang telah dibuat untuk mengumpulkan, menganalisis, mengidentifikasikan, mencatat dan melaporkan transaksi-transaksi suatu organisasi dan penyelenggaraannya dapat di pertanggung jawabankan.

\section{Sistem Informasi Akuntansi}

Menurut (Sofia, 2015) Sistem Informasi Akuntnasi adalah suatu kegiatan mengelompokkan, menggolongkan, mencatat dan memproses kegiatan bisnis perusahaan kedalam sebuah pelaporan keuangan sebagai suatu informasi bagi manajemen dan pihak lainnya. Sedangkan menurut (Sofia, 2015), sistem informasi akuntansi adalah "suatu komponen yang mengumpulkan, menggolongkan, mengolah, menganalisa, dan mengkombinasikan informasi keuangan yang relevan untuk pengambilan keputusan pihak-pihak luar (seperti pemerintah, masyarakat, investor, dan kreditor) pihak-pihak dalam (terutama manajemen)".

\section{Unsur-Unsur Sistem Akuntansi}

a. Formulir

Formulir merupakan dokumen yang digunakan untuk mencatat kejadian transaksi. Di dalam formulir terdapat data transaksi yang dapat dijadikan dasar dalam pencatatan.

b. Jurnal

Jurnal merupakan sistem akuntansi yang digunakan untuk mencatat, mengelompokkan transaksi sejenis dan meringkas data keuangan lainnya.

c. Buku besar

Buku besar terdiri dari kumpulan rekening-rekening yang berfungsi untuk meringkas data keuangan yang telah dicatat sebelumnya dalam jurnal. Rekening buku besar dianggap juga sebagai tempat penggolongan data keuangan untuk penyajian laporan keuangan.

d. Buku pembantu

Buku pembantu berisi rekeningrekening pembantu dalam merinci data keuangan, contohnya seperti mengelompokkan jenis transaksi yang terjadi di suatu perusahaan satu dengan yang lainnya.

e. Laporan

Laporan adalah hasil akhir dari proses akuntansi. Berupa neraca, laporan laba rugi, laporan perubahan modal, laporan biaya pemasaran, laporan harga pokok produksi, laporan harga pokok penjualan, daftar utang, daftar saldo persediaan 


\section{Tujuan dan Manfaat Sistem Informasi Akuntansi}

Tujuan atau manfaat sistem informasi akuntansi adalah sebagai berikut.

1. Mengamankan harta/kekayaan perusahaan. Harta kekayaan yang dimaksud meliputi kas perusahaan, persediaan barang dagangan, termasuk aset tetap perusahaan.

2. Mengahasilkan beragam informasi untuk pengambilan keputuasan.

3. Mengahasilkan informasi untuk pihak eksternal.

4. Menghasilkan informasi untuk penilaian kinerja karyawan atau divisi.

5. Menyediakan data masa lalu untuk kepentingan audit (pemeriksaan).

6. Menghasilkan informasi untuk penyusunan dan evaluasi anggaran perusahaan.

7. Menghasilkan informasi yang diperlukan dalam kegiatan perencanaan dan pengendalian.

Berdasarkan definisi sistem informasi akuntansi maka tujuan dan manfaat sistem informasi akuntansi tersebut adalah sebagai pengolah transaksi (transaction processing) dan pengolah informasi (information processing).

1. Pemrosesan Transaksi Transaksi memungkinkan perusahaan melakukan operasi, menyelenggarakan arsip dan catatan up on date, dan mencerminkan aktivitas organisasi. Transaksi akuntansi merupakan transaksi pertukaran yang mempunyai nilai ekonomis. Tipe transaksi dasar adalah : (1) penjualan produk atau jasa, (2) pembelian bahan baku, barang dagangan, jasa, dan aset tetap dari suplier, (3) penerimaan kas, (4) pengeluaran kas kepada suplier, dan (5) pengeluaran kas gaji karyawan. Sebagai pengolah transaksi, sistem informasi akuntansi berperan mengatur dan mengoperasionalkan semua aktivitas transaksi perusahaan.

2. Pengolahan Transaksi Tujuan kedua sistem informasi akuntansi adalah untuk menyediakan informasi yang diperlukan dalam pengambilan keputusan yang dilaksanakan oleh aktivitas yang disebut pemrosesan transaksi. Sebagian keluaran yang diperlukan oleh pemrosesan transaksi disediakan oleh sistem pemrosesan transaksi. Namun sebagian besar diperoleh dari sumber lain, baik dari dalam maupun dari luar perusahaan. Pengguna utama pemrosesan transaksi adalah manajer perusahaan. Mereka mempunyai tanggung jawab pokok untuk mengambil keputusan yang berkenaan dengan perencanaan dan pengendalian operasi perusahaan. Pengguna output lainnya adalah para karyawan penting seperti akuntan, insinyur, serta pihak luar seperti investor dan kreditor.

\section{Pengendalian Internal}

(Prabowo et al., 2021) Pengendalian internal memiliki definisi berupa: Internal control is a process carried out by a company's board of directors, management, and other employees to provide reasonable assurance that goals have been achieved in the following categories: (1) the effectiveness and efficiency of 
business operations; (2) reliability of financial information; (3) Compliance with applicable laws and regulations.

Dari definisi tersebut menunjukkan arti dari pengendalian internal yakni suatu penerapan metode oleh direksi, manajemen, serta pimpinan dengan cara memberi sebuah rasa optimis dalam mencapai tujuan, seperti:

(1) Keefektivan serta operasi yang tepatguna;

(2)Ketepatan pada pelaporan keuangan tahunan;

(3)Kepatuhanakan hukum sertaaturan.

Pengendalian internal tersusun atas 5 elemen, yakni:

1) Lingkungan

2) Penilaian ancaman

3) Kegiatan pengendalian

4) Informasi serta komunikasi

5) Pengawasan.

Pada dasarnya sistem tidak dapat mencegah adanya pemborosan serta kecurangan sepenuhnya, hal ini dikeranakan perusahaan mempunyai batasanbatasan yang mengikat. Didalam pengendalian intern keterbatasan yang melekat adalah:

1) Kekeliruan pada evaluasi manajemen maaupun karyawan, pada saat pengambilan putusan bisnis dan pelaksanaan tugas rutin, kurang mendapat informasi secara terperinci, kekurangan waktu, dan adanya tekanan lain.

2) Terjadinya kegagalan pada saat pengendalian bisa disebabkan akibat dari salah tafsir atas tugas yang diberikan, lalai dalam pelaksanaannya, kurang memperhatikan, dan kelelahan. Adanya perubahan baik temporer maupun tetap pada personel ataupun sistem serta prosedural

\section{Persediaan}

Persediaan merupakan barang - barang yang dimiliki oleh suatu perusahaan, yang diperoleh dari pembelian atau dari hasil produksi sendiri dengan tujuan untuk dijual kembali kepada konsumen (Suryadi, 2021) . Persediaan barang dagang adalah barang-barang yang dimilki perusahaan untuk dijual kembali. Persediaan pada umunya meliputi jenis barang yang cukup banyak dan merupakan bagian yang cukup berarti dari seluruh aktiva perusahaan.Disamping itu transaksi yang berhubungan dengan perusahaan merupakan aktivitas yang paling sering terjadi. 


\section{Jenis Persediaan}

Di bawah ini, ada beberapa jenis persediaan yang perlu kenal jika Anda adalah seorang pemilik bisnis. Berikut adalah beberapa jenis persediaan:

\section{Persediaan bahan baku}

Persediaan bahan baku mengacu pada barang yang digunakan untuk membuat produk atau persediaan perusahaan. Dengan kata lain, mereka adalah bahan yang dibutuhkan untuk memproduksi berbagai barang. Bahan baku bisa apa saja dari kayu dan paku untuk membuat perabot atau tepung, telur dan mentega yang digunakan untuk membuat produk untuk toko roti. Biaya bagian persediaan ini dilaporkan sebagai persediaan bahan baku di neraca perusahaan.

\section{Persediaan barang dalam proses}

Persediaan barang dalam proses mengacu pada barang yang belum selesai atau sepenuhnya diproduksi. Contoh jenis inventaris ini termasuk cokelat yang masih membutuhkan lapisan gula di pabrik cokelat, sepatu yang belum diwarnai, dan minyak esensial yang belum dikemas dalam botol oleh produsen kesehatan.

\section{Persediaan barang jadi}

Barang jadi mengacu pada produk atau persediaan yang siap dijual oleh perusahaan. Barang-barang ini telah menyelesaikan siklus produksi. Barang jadi sebelumnya terdiri dari bahan mentah dan juga barang dalam proses.

Contoh persediaan barang jadi termasuk barang jadi yang dipanggang di toko roti, kaos yang sudah jadi oleh perancang pakaian dan rumah yang sudah selesai oleh pembangun rumah.

\section{Metode pencatatan persediaan}

Persediaan memegang peranan yang sangat penting untuk menentukan hasil usaha atau pendapatan, (harga pokok barang yang terjual). Harus diketahui terlebih dahulu jumlah pembeliannya bersih persediaanpada awal periode akuntansi. Menurut (Indah \& Maulida, 2018) terdapat 2 macam metode pencatatan persediaan yaitu :

a. Sistem Periodik (fisik)

Penilaian persediaan dilakukan dengan menggunakan perhitungansecara fisik.Pencatatan transaksi persediaan barang dagangan dengan metode ini tidak langsung berkaitan dengan barang dagang yang bersangkutan. Misalnya bila terjadi pembelian barang dagangan akan dicatat pada rekening khusus yaitu pembelian (purchases) dan penjualan barang dagangan dicatat pada rekening penjualan. Pada waktu terjadi pembelian atau penjualan tidak dicatat rekening persediaan. Metode yang digunakan dalam sistem periodik antara lain:

1.Metode Tanda Pengenalan Khusus 
Metode ini biasanya digunakan untuk perusahaan yang spesifik danspesial yang menjual barang sedikit dan harga mahal. Setiap barangyang masuk diberi tanda pengenal khusus yang menunjukan harga satuan sesuai dengan faktur pembelian yang diterima.

\section{Metode Rata-Rata}

Cara penghitungan metode ini adalah dengan menghitung rata-rata dari harga beli dari jumlah yang dibeli selama periode tertentu.

\section{Metode First In First Out (FIFO)}

Dalam metode First In First Out(FIFO), barang yang lebih dulu masuk dianggap barang yang lebih dahulu keluar.

\section{Metode Last In First Out (LIFO)}

Dalam metode Last In First Out(LIFO), barang yang terakhir masuk dianggap barang yang terlebih dahulu keluar.

\section{Metode Persediaan Dasar}

Adakalanya perusahaan menetapkan jumlah minimum persediaan yang harus ada setiap saat, baik mengenai kuantitas maupun harga satuan, atau sering disebut persediaan dasar (basic stock). Menurut metode ini, nilai persediaan barang akhir periode dihitung:

a. Apabila kuantitas lebih banyak daripada kuantitas sediaan dasar,nilai persediaan adalah nilai dasar ditambah dengan harga pasar kelebihannya.

b.Apabila kuantitas lebih rendah daripada kuantitas sediaan dasar,nilai persediaan adalah nilai dasar dikurangi dengan harga pasar kekurangannya

\section{Prinsip Dasar Pengendalian Internal}

Ada beberapa asumsi dasar yang perlu dipahami mengenai pengendalian intern bagi suatu entitas organisasi atau perusahaan. Sistem pengendalian internal merupakan management responsibility. Bahwa sesungguhnya yang paling berkepentingan terhadap sistem pengendalian internal suatu entitas organisasi/ perusahaan adalah manajemen (lebih tegasnya lagi ialah top management / direksi), karena dengan sistem pengendalian internal yang baik itulah top management dapat mengharapkan kebijakan dipatuhinya, aktiva atau harta perusahaan dilindungi, dan penyelenggaraan pencatatan berjalan baik. Hasil perhitungan kas direkam dalam berita acara penghitungan kas dan disetor penuh ke bank dengan segera. Para penagih dan kasir harus diasuransikan (fidelity bond insurance). Kas dalam perjalanan (baik yang ada ditangan bagian kasir maupun di tangan penagih perusahaan) harus diasuransikan (Cash-in-safe dan cash-in-transit Insurance)

\section{Komponen Pengendalian Internal}

Pengendalian internal dalam suatu perusahaan sangat berguna dalam pengawasan harta kekayaan perusahaan. Agar tujuan sistem pengendalian internal perusahaan dapat dicapai dengan baik, maka 
selayaknya mempertimbangkan unsur-unsur atau komponen dari sistem pengendalian internal tersebut. Komponen pengendalian internal COSO terdiri dari hal-hal berikut :

1. Lingkungan Pengendalian

Lingkungan Pengendalian terdiri dari tindakan, kebijakan dan prosedur yang menggambarkan keseluruhan sikap manajemen, direksi, dan pemilik dari suatu entitas atas pengendalian internal dan pentingnya pengendalian internal tersebut terhadap entitas. Untuk memahami dan menilai lingkungan pengendalian, auditor harus mempertimbangan subkomponen pengendalian internal yang sangat penting :
a. Integritas dan Nilai Etika
b. Komitmen Terhadap Kompotensi
c. Partisipasi Dewan Direksi dan Komisaris atau Komite Audit
d. Filosofi Manajemen dan Gaya Operasi
e. Struktur Organisasi
f. Kebijakan dan Praktik Sumber Daya Manusia

2. Penilaian Risiko

Penilaian resiko untuk laporan keuangan merupakan identifikasi dan analisis manajemen terhadap risiko-risiko yang relevan terhadap penyusunan laporan keuangan sesuai dengan PABU. Proses penilaian risiko yaitu mengidentifikasi faktor-faktor yang memengaruhi risiko, menilai pentingnya risiko dan kemungkinan terjadinya, serta menentukan tindakan-tindakan yang perlu dilakukan untuk menangani risiko.

3. Aktivitas Pengendalian

Aktivitas pengendalian merupakan kebijakan dan prosedur, selain yang telah dimaksudkan dalam keempat komponen lainnya, yang membantu untuk meyakinkan bahwa tindakan-tindakan yang penting telah dilakukan untuk mengatasi risiko-risiko dalam mencapai tujuan organisasi. Terdapat kemungkinan banyak aktivitas pengendalian pada setiap entitas, termasuk pengendalian secara manual dan pengendalian secara otomatis. Aktivitas pengendalian tersebut umumnya termasuk kedalam salah satu dari kelima jenis aktivitas berikut :
a. Pemisahan tugas yang memadai.
b. Otorisasi yang tepat atas transaksi dan aktivitas.
c. Dokumentasi dan catatan yang memadai.
d. Pengendalian fisik atas aset dan catatan-catatan.
e. Pengecekan terhadap pekerjaan secara independen.

4. Informasi dan Komunikasi 
Tujuan dari sistem informasi dan komunikasi akuntansi suatu entitas adalah untuk memulai, mencatat, memproses, dan melaporkan transaksi-transaksi yang terjadi dalam suatu entitas dan untuk menjaga akuntabilitas aset-aset yang terkait. Sebuah sistem informasi dan komunikasi akuntansi memiliki beberapa subkomponen, biasanya membentuk suatu kelompok transaksi seperti penjualan, retur penjualan, penerimaan kas, pembelian dan lainlain. Untuk setiap kelompok transaksi, sistem akuntansi harus memenuhi keenam tujuan audit terkait transaksi seperti keterjadian, kelengkapan, akurasi, pemindahbukuan dan pengikhtisaran, klasifikasi, dan waktu.

5. Pengawasan Aktivitas

pengawasan berkaitan dengan penilaian yang berjalan atau penilaian berkala atas kualitas pengendalian internal oleh manajemen untuk menentukan bahwa pengendalian dijalankan sesuai dengan tujuannya dan dimodifikasi jika diperlukan terjadi perubahan kondisi. Informasi yang dinilai berasal dari berbagai sumber, termasuk studi atas pengendalian internal yang sudah ada, laporan internal auditor, laporan pengecualian atas aktivitas pengendalian, laporan dari regulator misalnya dari regulator perbankan, umpan balik dari personel operasi, dan keluhan-keluhan dari pelanggan mengenai biaya penagihan. Untuk beberapa perusahaan, biasanya perusahaan besar, departemen audit internal merupakan fungsi penting untuk melakukan pengawasan efektif.

Agar menjadi efektif, fungsi pengendalian internal harus dijalankan oleh staf yang independen dari departemen operasi maupun dari departemen akuntansi dan melaporkan langsung kepada otoritas yang lebih tinggi dalam organisasi, apakah pada manajemen puncak atau pun pada komite audit dari dewan direksi. Mulyadi (2015:164) menyatakan bahwa unsur pokok sistem pengendalian intern adalah :

1. Struktur Organisasi Yang Memisahkan Tanggung Jawab Fungsional Secara Tegas.

Pembagian tanggung jawab fungsional dalam organisasi ini didadasarkan pada prinsipprinsip berikut ini:

a) Harus dipisahkan fungsi-fungsi operasi dan penyimpanan dari fungsi akuntansi.

b) Suatu fungsi tidak boleh diberi tangung jawab penuh untuk melaksanakan seluruh tahap suatau transaksi.

2. Sistem Wewenang dan Prosedur Pencatatan Yang Memberikan Perlindungan Yang Cukup Terhadap Kekayaan, utang, pendapatan, biaya.

Dalam organisasi, setiap transaksi hanya terjadi atas dasar otoritas dari pejabat yang memiliki wewenang untuk menyetujui terjadinya transaksi tersebut. Oleh karena itu, dalam organisasi harus dibuat sistem yang mengatur pembagian wewenang untuk otorisasi atas terlaksananya setiap transaksi. Prosedur pencatatan yang baik akan menjamin data yang direkam dalam formulir dicatat dalam catatan akuntansi dengan tingkat ketelitian dan keandalannya yang tinggi. 
3. Praktik Yang Sehat Dalam Melaksanakan Tugas Dan Fungsi Setiap Unit Organisasi.

Adapun cara-cara yang umumnya ditempuh oleh perusahaan dalam menciptakan praktik yang sehat adalah :

a. Penggunaan formulir bernomor urut tercetak yang pemakaiannya harus dipertanggungjawabkan oleh yang berwenang.

b. Pemeriksaan mendadak (surprised audit),

c. Setiap transaksi tidak boleh dilaksanakan dari awal sampai akhir oleh satu orang atau satu unit organisasi, tanpa ada campur tangan dari orang atau unit organisasi lain,

d. Perputaran jabatan (job rotation),

e. Keharusan pengambilan cuti bagi karyawan yang berhak,

f. Secara periodik diadakan pencocokan fisik kekayaan dengan catatannya,

g. Pembentukan unit organisasi yang bertugas untuk mengecek efektivitas unsur-unsur sistem pengendalian intern yang lain.

4. Karyawan Yang Mutunya Sesuai Dengan Tanggung Jawabnya.

Untuk mendapatkan karyawan yang kompoten dan dapat dipercaya, berbagai cara berikut ini dapat ditempuh:

a. Seleksi calon karyawan berdasarkan persyaratan yang dituntut oleh pekerjaannya,

b. Pengembangan pendidikan karyawan selama menjadi karyawan perusahaan, sesuai dengan tuntutan perkembangan pekerjaannya.

\section{METODE PENELITIAN}

\section{Jenis Penelitian :}

Dalam penelitian ini penulis menggunakan metode deskriptif kualitatif. Data kualitatif merupakan informasi dalam bentuk kalimat bukan berupa angka maupun symbol. Dengan menggunakan penelitian kualitatif, peneliti dapat mengetahui subyek dan mengetahui keadaan yang dialami mereka dalam kehidupan sehari-hari. Penelitian kualitatif juga menghasilakn data deskriptif. Data deskriptif merupakan data yang rinci, menjelaskan suatu masalah dengan jelas sampai ke akarnya, dan menjelaskan suatu fenomena secara detail. Metode ini bertujuan untuk mengetahui gambaran jelas menganai masalah dengan utuh dan sesuai fakta sesuai gambaran manusia yang melakukan penelitian. 


\section{Subjek Penelitian}

Subyek penelitian ini adalah kedai Kopi Ledokan di Binangun Obyek pada penelitian ini yaitu data mengenai system informasi dan pengendalian internal persediaan bahan baku dikedai kopi tersebut.

\section{Teknik Pengumpulan Data}

aMengumpulkan data

Pada kegiatan ini, penulis melakukan pengumpulan data guna untuk menunjang pembangunan sistem. Pengumpulan data dilakukan dengan cara wawancara yaitu melakukan tanya jawab pada toko yang menjadi tempat penulis untuk melakukan pembangunan sistem ini. Selain itu penulis juga mengumpulkan data dengan cara studi literatur yang bertujuan sebagai panduan untuk melakukan pembangunan sistem dan sebagai panduan untuk pembuatan laporan mini riset ini.

b. Menentukan ruang lingkup

Pada kegiatan ini, penulis menentukan ruang lingkup dalam pembuatan jurnal ini Menentukan ruang lingkup tersebut dilakukan penulis ini memiliki batasan - batasan mengenai apa yang akan dibuat dan dikerjakan .

\section{Teknik Analisa Data}

1. Reduksi Data;

Reduksi data merupakan pemusatan perhatian, proses pemilihan pada pengabstrakan, penyederhanaan dan transformasi data yang kasar yang muncul dari catatan dilapangan

2. Penyajian Data;

Penyajian data ini tersusun berbagai informasi yang bisa terjadi pengambilan keputusan dan penarikan kesimpulan. Setelah itu penyajian data digunakan agar dapat memahami masalah yang diteliti serta dianalisis sesuai dengan tujuan yang diinginkan.

3. Menarik Kesimpulan;

Menarik kesimpulan dengan cara pengembangkan sebuah paragraf lalu menarik sebuah gagasan utama dan simpulan umum berdasarkan kerjadian yang ada. Selain itu penarikan kesimpulan dapat dilakukan dengan cara pengembangan sebuah paragraf menggunkan sebab akibat . kesimpulan hanyalah sebuah sebagian dari pembahasan yang ada. Kesimpulan dibuat agar pembeca bisa memahami secara singkat dari pembahasan sebelumnya. Saat penelitian berlangsung kesimpulan juga diverifikasi terlebih dahulu. 
Dalam Artikel ini menggunakan metode analisis data kualitatif. Metode analisis data kualitatif adalah pendekatan pengolahan secara mendalam data hasil pengamatan, wawancara, dan dari data angket yang telah kami buat. Sistematika atau urutan yang ada dalam penelitian memberikan pola berfikir secara sistematis , komplek dan mampu mengungkan gejala yang ada dimsyarakat secara sistematis. Penelitian kualitatif tidak dapat ditolak kebenarannya oleh masyarakat, karena penelitian ini dibuat sesuai keadaan nyata dilapangan.

\section{Instrumen Penelitian}

\section{Studi kepustakaan}

Studi kepustakaan ini dilakukan dengan cara membaca literatur-literatur yang berhubungan dengan permasalahan yang sedang diteliti dan dapat dijadikan sebagai landasan teoritis bagi pembahasan masalah.

2. Metode interview (wawancara)

Metode wawancara dilakukan dengan cara wawancara dengan pihak-pihak yang terkait dengan penelitiaan. Seperti pemilik kedai kopi Ledokan dan karyawannya.

\section{HASIL PENELITIAN DAN PEMBAHSAN}

A. Fungsi yang terkait dalam Sistem Informasi Akuntansi Persediaan Bahan Baku kedai kopi Ledokan. 1. Fungsi Pembelian

Fungsi pembelian yang dimaksud mengenai barang baku yang dibeli dari pemasok atau membeli sendiri atau bisa disebut juga mengorder barang. Menurut Bapak Dwi selaku pemilik kedai kopi Ledokan mengatakan untuk membeli bahan baku dia turun tangan sendiri dalam berbelanja bahan baku. Dia membeli bahan baku berupa keperluan pembuatan kopi dan berbagai minuman dingin lainnya dalam dua minggu sekali. Menurutnya, dia mampu berbelanja bahan baku ketempat yang lebih jauh agar mendapatkan harga yang miring atau termurah.

2. Fungsi Penerimaan Barang 
Fungsi penerimaan barang merupakan tanggung jawab dari karyawan. Dari 4 karyawan yang bekerja, hanya ada 1 admin atau yang mencatat bagian pemasukan dan pengeluaran uang. Admin ini jua bertanggung jawab untuk mencatat bahan baku yang sudah dibeli ke bagian pembelian bahan baku. Admin mengecek kesesuain antara barang yang dibeli dengan faktur dan purchase order yang sebelumnya sudah dibuat. Admin juga mengarsipkan surat nota pembelian untuk dijadikan bahan bukti kas keluar.

\section{Fungsi Gudang}

Fungsi gudang untuk mengetahui persedian bahan baku yang masih ada atau sudah habis. Fungsi gudang ini sangat penting untuk proses pelancaran penjualan. Menurut Bapak Dwi mengatakan bahwa, karyawannya harus melaporkan 2 minggu sekali sebelum belanja bahan baku mengenai bahan baku apa saja yang haru dibeli. Karyawannya selalu mengecek kesesuaian antara catatan dengan kondisi fisik persediaan. Jika persediaan hampir habis penjaga gudang membuat daftar barang yang hampir habis dan membuat laporan yang diserahkan kepada admin. Hal ini dilakukan untuk mengetahui bahan baku apa saja yang stoknya habis dan akan dilakukan permintaan produksi.

\section{Fungsi Quality Contol dan Pengawasan}

Fungsi kontrol dan pengawasan ini merupakan hal penting dalam kegiatan operasional. Karena kita harus mengawasi kualitas produk yang dihasilkan dan juga mengontrol pemakaian bahan baku agar tidak menyebabkan pemakaian yang berlebihan.

\section{Fungsi Keuangan}

Fungsi keuangan ini bertanggung jawab mengenai aliran kas masuk dan kas keluar. Tanggung jawab tersebut merupakan tugas. Pelaporan keuangan ini digunakan untuk mengetahui pengeluaran yang masuk dalam periode satu bulan, dan tidak lupa untuk mencatat pengeluaran bahan baku, peralatan yang menunjang, serta biaya-biaya yang dibebanan sebagai operasional kegiatan yang berlangsung. Fungsi keuangan menurut Bapak Dwi sangat penting untuk mengambil keputusan yang akan dibuat dikemudian hari .

\section{B. Metode Persedian Bahan Baku}

Kedai Kopi Ledokan mencari dan mendapatkan supplier produsen biji kopi dengan kualitas biji yang baik. Tujuannya adalah untuk mendapatkan biji kopi berkualitas baik dan mengurangi biaya karena mereka membeli langsung dari petani. Petani juga diuntungkan dari proses ini karena mendapatkan harga yang sesuai dengan kualitas biji yang mereka jual. Strategi yang digunakan Kedai Kopi Ledokan adalah strategi pemilihan pemasok dengan banyak pemasok. Strategi ini dinilai tepat karena Kedai Kopi Ledokan membutuhkan pemasok dengan harga murah dan kualitas produk yang baik. Dengan pemilihan supplier yang banyak, Kedai Kopi Ledokan akan selalu menyediakan sumber bahan baku dengan kualitas dan kuantitas yang sesuai dengan yang diharapkan. Ini akan mencegah toko runtuh ketika ada kekurangan bahan. 
Dalam proses rantai pasok di Kedai Kopi Ledokan, distributor dan pengecer tidak berperan. Memang, bahan produksi Kedai Kopi Ledokan berasal dari petani atau produsen. Sedangkan Kedai Kopi Ledokan sendiri berperan sebagai pengolah yang menjual langsung ke konsumen. Oleh karena itu, rantai pasok Kedai Kopi Ledokan hanya terdiri dari 3 komponen, yaitu petani sebagai pemasok, Kedai Kopi Ledokan sebagai pengolah dan pelanggan adalah konsumen.

Manajemen distribusi untuk mendukung keberhasilan manajemen pasokan di Kedai Kopi Ledokan adalah proses pengiriman biji kopi dari petani ke Kabupaten Blitar dari gudang atau tempat penyimpanan ke Kedai Kopi Ledokan. Selama proses pengiriman, pemilik Kedai Kopi Ledokan memilih bahan baku sendiri kopi dari petani di sekitar Blitar. Sedangkan kopi dari luar Kabupaten Blitar dikirim melalui kurir. Ketika biji kopi sudah matang, biji kopi tersebut akan dipisahkan menjadi 2 yaitu untuk disangrai (roasting) dan untuk disimpan di gudang. Proses roasting atau penyangraian bertujuan untuk mengeluarkan cita rasa kopi dan kemudian kopi siap untuk melanjutkan ke langkah selanjutnya. Langkah selanjutnya akan dilakukan oleh seorang Bartender dimana Bartender tersebut berada.

Sumber bahan baku yang baik juga harus memiliki sistem pengendalian persediaan yang baik. Kedai Kopi Ledokan adalah kedai kopi yang menggunakan sistem manajemen persediaan first in first out (FIFO). Dalam sistem manajemen persediaan ini, setiap item yang datang lebih dulu digunakan terlebih dahulu. Berikut perhitungan menggunakan sistem perpetual FIFO Kedai Kopi Ledokan , dimana semua bahan digabungkan dan diurutkan berdasarkan tanggal.

Tabel 1

Sistem perpetual FIFO (First In First Out) dalam 1 tahun

\begin{tabular}{|c|l|l|l|l|l|l|l|l|l|}
\hline \multirow{2}{*}{ Tgl } & \multicolumn{3}{|c|}{ Pembelian } & \multicolumn{3}{c|}{ Harga pokok penjualan } & \multicolumn{3}{c|}{ Persediaan } \\
\cline { 2 - 11 } & Unit & $\begin{array}{c}\text { Harga/ } \\
\text { unit }\end{array}$ & $\begin{array}{c}\text { Total } \\
\text { harga }\end{array}$ & Unit & $\begin{array}{c}\text { Harga/ } \\
\text { unit }\end{array}$ & $\begin{array}{c}\text { Total } \\
\text { harga }\end{array}$ & Unit & $\begin{array}{c}\text { Harga/ } \\
\text { unit }\end{array}$ & $\begin{array}{c}\text { Total } \\
\text { harga }\end{array}$ \\
\hline $01 / 01$ & - & - & - & - & - & - & 100 & 12.000 & 1.200 .000 \\
\hline $05 / 02$ & 300 & 35.000 & 10.500 .000 & - & - & - & 100 & 17.000 & 3.400 .000 \\
\hline $20 / 03$ & - & - & - & 80 & 5.000 & 400.000 & 500 & 5.000 & 2.500 .000 \\
\hline $15 / 04$ & - & - & - & 200 & 17.000 & 3.400 .000 & 300 & 17.000 & 5.100 .000 \\
\hline $22 / 05$ & 200 & 15.000 & 3.000 .000 & - & - & - & 100 & 12.000 & 1.200 .000 \\
\hline
\end{tabular}




\begin{tabular}{|l|l|l|l|l|l|l|l|l|l|}
\hline $01 / 06$ & - & - & - & 275 & $12 . .000$ & 3.300 .000 & 100 & 5.000 & 500.000 \\
\hline $01 / 07$ & 225 & 13.000 & 2.925 .000 & - & - & - & 200 & 5.000 & 1.000 .000 \\
\hline $04 / 08$ & - & - & - & & & & 150 & 17.000 & 2.550 .000 \\
\hline $16 / 09$ & 200 & 15.000 & 3.000 .000 & & & & 200 & 12.000 & 2.400 .000 \\
\hline $09 / 10$ & 170 & 36.000 & 6.120 .000 & - & - & - & 100 & 5.000 & 500.000 \\
\hline $11 / 11$ & - & - & - & 500 & 5.000 & 2.500 .000 & 275 & 5.000 & 1.375 .000 \\
\hline $05 / 12$ & 100 & 17.000 & 1.700 .000 & 350 & 17.000 & 5.950 .000 & 100 & 17.000 & 1.700 .000 \\
\hline Total & 1195 & 131.000 & 16.755 .000 & 1.405 & 56.000 & 12.490 .000 & 2.225 & 129.000 & 23.425 .000 \\
\hline
\end{tabular}

Selanjutnya peneliti membandingkan apakah pengendalian persediaan telah digantikan oleh sistem pengendalian persediaan dengan menggunakan sistem ABC. Jenis bahan berdasarkan sistem ABC adalah: 1. Grade A adalah bahan baku dengan perbandingan nilai yang tinggi, dalam hal ini biji kopi yang merupakan bahan utama untuk toko. Biji kopi memiliki total 20ri bahan di toko, tetapi nilainya bisa naik hingga 80ri dari total nilai bahan di toko.

2. Grade B adalah bahan baku dengan persentase nilai sedang, khususnya matcha adalah bahan sekunder dalam Kedai Kopi Ledokan ini. Matcha memiliki nilai 15, nilai total bahan-bahan di toko. Sedangkan jumlah tersebut merupakan 30 persen dari total jumlah bahan baku.

3. Grade $\mathrm{C}$ adalah bahan baku yang nilai presentasinya rendah tetapi dalam jumlah banyak. Di Kedai Kopi Ledokan, item dalam grup $\mathrm{C}$ adalah susu, gula, roti dan selai, yang bahan-bahan ini menyumbang 50ri dari total jumlah bahan baku di toko, tetapi nilai bahan-bahan kelas $\mathrm{C}$ hanya 5 juta dari total nilai bahan baku. bahan dari komponen di toko.

Dari hasil pengelompokan tersebut dapat diketahui bahwa kopi merupakan bahan baku golongan A yang memerlukan syarat pengendalian yang lebih ketat dibandingkan bahan baku golongan B dan C lainnya karena nilainya yang besar.

Berdasarkan analisis di atas, dapat disimpulkan bahwa manajemen pengendalian persediaan yang baik untuk toko adalah dengan metode $\mathrm{ABC}$. Dengan menggunakan metode $\mathrm{ABC}$, lebih mudah untuk mengidentifikasi dan membedakan bahan dengan prioritas tertinggi, sehingga tidak ada bahan yang disimpan di luar tanggal kedaluwarsa. Ini juga membantu mengurangi jumlah stok yang ada saat ini, sehingga modal toko dapat diputar dan digunakan untuk mengembangkan toko.

Tabel 2

Nilai Presentase Dana (dalam Rupiah) Setiap Jenis Bahan Baku (dalam Persen)

\begin{tabular}{|c|c|c|c|c|c|c|}
\hline \multirow{2}{*}{ No } & Jenis & Satuan & $\begin{array}{c}\text { Kuantitas } \\
\text { pemakaian } \\
\text { cetakan }\end{array}$ & Satuan satuan & Nilai & Penyerapan \\
& & $\left(\mathrm{D}_{1}\right)$ & $\begin{array}{c}\text { penerapan } \\
\text { dana }\left(\mathrm{M}_{1}\right)\end{array}$ & dana $\left(\mathrm{P}_{1}\right)$ \\
\hline
\end{tabular}




\begin{tabular}{|c|l|c|c|c|c|c|}
\hline 1 & Biji Kopi & Kg & 250 & 35.000 & 8.750 .000 & $45,7 \%$ \\
\hline 2 & Susu & Pack & 130 & 15.000 & 1.950 .000 & $10,1 \%$ \\
\hline 3 & Gula & Kg & 135 & 13.000 & 1.755 .000 & $9,1 \%$ \\
\hline 4 & Matcha & Kg & 120 & 36.000 & 4.320 .000 & $22,5 \%$ \\
\hline 6 & Roti & Pack & 100 & 15.000 & 1.500 .000 & $7,8 \%$ \\
\hline 7 & Selai & Botol & 50 & 17.000 & 850.000 & $4,4 \%$ \\
\hline
\end{tabular}

C. Sistem Pengendalaian Intern pada kedai kopi ledokan di binangun Blitar

Dari penelitian yang kami lakukan Sistem pengendalian intern yang digunakan oleh kedai kopi ledokan di binangun blitar sudah bisa dikatakan baik jika kita lihat dari unsur organisasi dilihat dari unsur organisasi, unsur organisasi ini tidak memiliki fungsi ganda seperti halnya prosedur pencatatan dan sistem otorisasi. Sistem otorisasi dan prosedur pencatatan sudah bangat baik, karena juika dilihat dari surat order pembeliannya dibuat berdasarkan kebutuhan perusahaan dalam periode satu minggu dan diotoritaskan oleh kepala bagian pembelian sehingga pembelian produk masuk tidak lebih atau kurang dari jumlah produk yang diorder. Ketika barang yang telah diterima nantinya akan dicatat dalam laporan pembelian, yang nanti kemuadian bertanggungjawab untuk menindaklanjuti setiap masalah/ kerusakan/kehilangan di bagian. Penyimpanan persediaan barang diluar gudang juga harus mengantongi persetujuan dari manajer Kedai Kopi Ledokan. Persediaan barang dagangan ini harus dilindungi dengan asuransi dari resiko-resiko terburuk yang mungkin bisa terjadi seperti banjir, kebakaran, bahaya lainnya.

Berikut adalah kebijakan-kebijakan serta praktek sumber daya manusia yang telah kami rangkum yang diterapkan pada kedai kopi ledokan binangun :

a. Dalam hal perekrutan karyawan baru tentunya dilakukan atas dasar pertimbanganpertimbangan sesuai dengan kebutuhan Kedai Kopi Ledokan

b. Pelatihan karyawan baru dilakukan oleh bagian-bagian yang mempunyai cukup banyak pengalaman dalam bidangnya.

c. Motivasi yang diberikan kepada karyawan pada kedai kopi ledokan dilakukan agar para karyawan dapat menambah semangat bekerja dan menambah kinerja

d. Memberikan penghargaan kepada para karyawan yang mempunyai etos kerja yang baik dan berprestasi, hal ini dilakukan untuk memacu mereka untuk bekerja lebih baik lagi 
e. Perlindungan tehadap para karyawan yang diberikan oleh kedai kopi ledokan berdasarkan atas standar K3 (Keselamatan Kesehatan Kerja).

\section{PENUTUP}

\section{KESIMPULAN}

Berdasarkan analisis di atas, dapat disimpulkan bahwa Kedai Kopi Ledokan memiliki kemampuan supply chain management yang baik yang dibuktikan dengan adanya pemasok yang memiliki hubungan kerjasama jangka panjang dengan mereka. Biji kopi yang diperoleh berkualitas tinggi sehingga mampu menciptakan cangkir kopi yang nikmat untuk melayani kebutuhan kenikmatan pelanggan. Di samping itu. Kedai Kopi Ledokan juga bisa menghemat uang dari vendor ini. Namun dalam hal pengendalian persediaan, Kedai Kopi Ledokan perlu melakukan beberapa perubahan metodologis untuk mengurangi biaya dan memutar modal secara lebih efisien dengan sistem pengendalian persediaan ABC. Keputusan tentang pengelolaan biaya produksi juga berdampak positif pada kopi ini, sehingga memberikan keuntungan yang stabil.

\section{SARAN}

Berdasarkan hasil penelitian dan kesimpulan, maka pada bagian ini penulis mencoba untuk memberikan saran yang diharapkan akan bermanfaat bagi perusahaan pada masa yang akan datang.

1. Perusahaan sebaiknya membuat pemisahan tugas pembelian serta menambahkan fungsi pengendaliaan di bagian gudang agar lebih efesien dan terciptanya pengendalian intern yang lebih baik lagi serta tidak terjadi adanya perangkapan tugas

2. Sebaiknya untuk perhitungan fisik persediaan dilakukan oleh karyawan selain bagian gudang, misal bagian pembukuan dengan bagian kas. Agar sistem pengendalian intern dalam prosedur pencatatan lebih baik lagi.

3. Menciptakan suatu sistem berbasis komputer untuk membantu dalampencatatan dan pencegahan resiko kehabisan stock bahan baku. 


\section{DAFTAR PUSTAKA}

Indah, D. rosa, \& Maulida, Z. (2018). Pengendalian Persediaan Bahan Baku Pada PT. Aceh Rubber Industries Kabupaten Aceh Tamiang. Jurnal Manajemen Dan Keuangan, 7(2), 157. https://doi.org/10.33059/jmk.v7i2.814

Kusnendi. (2012). Konsep Dasar Sistem Informasi. Lecture Notes : Sistem Informasi, 1-10.

Prabowo, R. G. M., Hariyanti, T. P., \& Marlena. (2021). Analisis Pengendalian Internal pada Implementasi Anggaran Kegiatan Lindik Dalam Menunjang Efektivitas Pengelolaan Administrasi. 5(1), 1124-1135.

Sofia, I. P. (2015). Modul Sistem Informasi Akuntansi (Sistem Pemrosesan Transaksi). Universitas Pembangunan Jaya, 50.

Suryadi, A. (2021). Persediaan barang. Angewandte Chemie International Edition, 6(11), 951-952., 2013-2015. 